\title{
EFEKTIVITAS ANTIMIKROBA BUAH LAKUM (Cayratia trifolia [L.] DOMIN) TERHADAP PERTUMBUHAN BAKTERI Streptococcus sp. (L.10.3)
}

\author{
Helenda Ferni Asri Yuniar ${ }^{{ }^{*}}$, Rahmawati ${ }^{1}$, Diah Wulandari Rousdy ${ }^{1}$ \\ ${ }^{1}$ Program Studi Biologi, Fakultas Matematika \& Ilmu Pengetahuan Alam, Universitas Tanjungpura \\ Jl. Prof. Dr. H. Hadari Nawawi, Pontianak, Kalimantan Barat \\ "Email: helendaferny@gmail.com
}

\begin{abstract}
Streptococcus sp. (L.10.3) is one of the bacteria that can cause dental plaque. This study was aimed to determine the antimicrobial activity of the fraction of methanol fraction of fruit against Streptococcus sp. (L.10.3). This study used a Completely Randomized Design (CRD), 3 levels of concentrations of fraction methanol fraction 0.3 $\mathrm{g} / \mathrm{mL}, 0.6 \mathrm{~g} / \mathrm{mL}$ and $0.9 \mathrm{~g} / \mathrm{mL}$ and 2 positive control treatments of amoxicillin and negative control using distilled water with three times repeated. Testing the antibacterial activity using the Kirby-Bauer method using disc paper. The results of the study showed the average diameter of inhibition zones of Streptococcus sp. (L.10.3) in the 24th hour incubation ranged from 7.70-10.72 $\mathrm{mm}$ and in the 48th hour incubation ranged from $8.70-10.37 \mathrm{~mm}$. A concentration of $0.9 \mathrm{~g} / \mathrm{mL}$ is an effective concentration with a moderate inhibition response category. Giving fraction of methanol fraction of fruit at the lowest concentration of $0.3 \mathrm{~g} / \mathrm{mL}$ is able to provide a moderate inhibition response with the bacteriocidal antibacterial category.
\end{abstract}

Keywords: Antimicroba, Lakum (Cayratia trifolia), Streptococcus sp.

\section{PENDAHULUAN}

Berdasarkan informasi dari masyarakat etnis melayu bahwa buah lakum bisa dijadikan obat sebagai obat pembersih gigi (Prasetyo et al., 2016). Antimikroba yang terkandung dalam tumbuhan diketahui memiliki efek samping kecil dan sangat potensial dalam mengobati penyakit infeksi (Janovska et al., 2003). Tumbuhan juga memiliki spesifikasi khasiat yang sangat unik karena dalam satu jenis tumbuhan dapat memiliki khasiat yang beragam (Mahendra, 2010). Salah satunya buah lakum (C. trifolia) mengandung kalsium oksalat yang digunakan untuk iritasi pada mulut (Grubben, 2004).

Salah satu bakteri patogen pada manusia adalah bakteri anggota spesies Streptococcus sp. Bakteri anggota spesies Streptococcus sp. merupakan bakteri anaerob fakultatif gram positif dikenal dapat menghasilkan asam laktat sebagai bagian dari hasil metabolisme yang berguna untuk hidup bakteri tersebut (Putri et al., 2017). Infeksi dari anggota spesies Streptococcus sp. dapat menyerang mulai dari anak-anak hingga dewasa dan lanjut usia. Bakteri anggota spesies Streptococcus sp. (L.10.3) merupakan bakteri yang diisolasi dari karies gigi (Susanti et al., 2018). Plak gigi terbentuk dengan melibatkan fermentasi yang dilakukan oleh bakteri utama penyebab karies yakni $S$. mutans yang mampu memproduksi glukosil transferase (GTF) yang dapat mengubah sukrosa menjadi glukan dan selanjutnya membentuk plak gigi (Putri et al., 2017). Belum ada informasi penggunaan fraksi metanol buah lakum sebagai antimikroba terhadap pertumbuhan bakteri Streptococcus sp. (L.10.3).

\section{BAHAN DAN METODE}

\section{Waktu dan Tempat}

Penelitian ini dilakukan selama dua bulan, yaitu bulan Mei sampai Juni 2019. Pengukuran kekeruhan suspensi bakteri menggunakan spektofotometer dilaksanakan di Laboratorium Kimia Fakultas Matematika dan Ilmu Pengetahuan Alam, Universitas Tanjungpura. Uji aktivitas antimikroba fraksi metanol buah lakum (C. trifolia) terhadap pertumbuhan bakteri Streptococcus sp. (L.10.3) dilaksanakan di Laboratorium Mikrobiologi, Jurusan Biologi, Fakultas Matematika dan Ilmu Pengetahuan Alam, Universitas Tanjungpura, Pontianak.

\footnotetext{
Alat

Alat yang digunakan dalam penelitian ini di antaranya yaitu aluminium foil, autoklaf, Biological Safety Cabinet (BSC), hotplate, inkubator, jangka sorong, jarum ose, kamera, kertas cakram $6 \mathrm{~mm}$,
} 
magnetic stirrer, mortar, peralatan gelas, pinset, pipet tetes, plastik, spatula, spektrofotometer UVVis, timbangan analitik, vortex, dan wrapping.

\section{Bahan}

Bahan yang digunakan dalam penelitian ini diantaranya akuades, antibiotik amoxicillin, fraksi metanol buah lakum (C. trifolia) hasil fraksi oleh Wulandari et al. (2018), media Mueller Hinton Agar (MHA), $\mathrm{NaCl}$ 0,9\% dan biakan isolat anggota bakteri Streptococcus sp. (L.10.3) hasil isolasi oleh Susanti et al., (2018) dari koleksi Laboratorium Mikrobiologi, Program Studi Biologi, Fakultas Matematika dan Ilmu Pengetahuan Alam, Universitas Tanjungpura, Pontianak, Kalimantan Barat.

\section{Cara Kerja}

\section{Sterilisasi Alat dan Pembuatan Media}

Alat-alat yang seperti cawan petri dibungkus dengan kertas, tabung reaksi, gelas ukur dan erlenmeyer masing-masing dibungkus menggunakan plastik kemudian disterilisasi menggunakan autoklaf selama 20 menit pada suhu $121{ }^{\circ} \mathrm{C}$. Media Mueller Hinton Agar (MHA) sebanyak 38 gram dimasukkan ke dalam gelas beaker dengan menambahkan 1 L akuades, kemudian dipanaskan hingga mendidih di atas hot plate sambil dihomogenkan dengan menggunakan magnetic stirrer, setelah media mendidih simpan di dalam erlenmeyer, kemudian media tersebut disterilisasikan dengan autoklaf pada suhu $121^{\circ} \mathrm{C}$ selama 15 menit dan tekanan 2 atm (Ramadanti, 2008).

\section{Pemurnian Mikroba}

Biakan bakteri Streptococcus sp. (L.10.3) sebanyak satu ose diinokulasikan dalam media Nutrient Agar (NA) yang telah membeku secara terpisah dan aseptis dengan meletakkan jarum ose yang mengandung biakan pada dasar agar dan ditarik dengan gerakan zig-zag (metode streak). Selanjutnya diinkubasi dalam inkubator pada suhu $37{ }^{\circ} \mathrm{C}$ selama 24 jam (Angelina et al., 2015).

\section{Pembuatan Suspensi Bakteri Uji}

Bakteri uji yang telah diinokulasikan diambil dengan jarum ose steril lalu disuspensikan kedalam tabung yang berisi $9 \mathrm{~mL}$ larutan Natrium Chloride $(\mathrm{NaCl}) \quad 0,9 \%$, kemudian diukur kekeruhannya dengan nilai Optical Density (OD) 0,060-0,086 menggunakan spektofotometer pada panjang gelombang $600 \mathrm{~nm}$. Perlakuan yang sama dilakukan pada setiap jenis bakteri uji (Nuria, 2010).

\section{Uji Aktivitas Antibakteri}

Metode pengujian yang digunakan metode uji Kirby-Bauer dengan menggunakan kertas cakram. Suspensi bakteri Streptococcus sp. (L.10.3) yang sudah diukur kekeruhannya dengan nilai OD 0,0600,086 diambil sebanyak $1 \mathrm{ml}$ lalu dimaksukkan ke dalam cawan petri dan ditambahkan media MHA sebanyak $19 \mathrm{ml}$, kemudian dihomogenkan dan ditunggu sampai media membeku. Kertas cakram yang telah direndam dengan akuades (kontrol negatif), antibiotik amoxicillin (kontrol positif) dan fraksi metanol buah lakum dengan konsentrasi perlakuan $0,3,0,6$ dan $0,9 \mathrm{~g} / \mathrm{mL}$, selama \pm 15 menit kemudian diletakan diatas media MHA yang telah terdapat biakan bakteri (Gambar 1). Kemudian diinkubasi dalam inkubator pada suhu $37{ }^{\circ} \mathrm{C}$ selama 24 jam dan 48 jam.

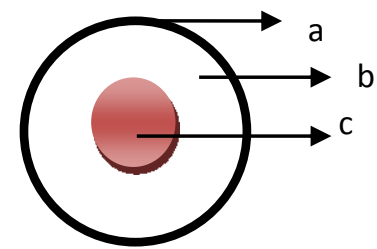

Gambar 1. Peletakan kertas saring pada media uji, (a) cawan petri; (b) media MHA yang sudah terdapat biakan bakteri; (c) kertas cakram.

Zona hambat yang terbentuk pada inkubasi jam ke24 dan ke-48 setelah pengujian, diukur dan dibandingkan dengan kontrol positif. Pengukuran diameter zona hambat dilakukan untuk menentukan kekuatan daya hambat fraksi metanol buah lakum (C. trifolia) terhadap bakteri anggota spesies Streptococcus sp. (L.10.3). Diameter zona hambat yang terbentuk pada inkubasi jam ke-24 dan 48 dikategorikan berdasarkan kategori respon hambat menurut Davis \& Stout (1971) (Tabel 1).

Tabel 1. Kategori Respon Hambatan Pertumbuhan Bakteri

\begin{tabular}{cc}
\hline Diameter Zona Hambat & Respon Hambatan \\
\hline$\geq 20 \mathrm{~mm}$ & Sangat Kuat \\
$11-19 \mathrm{~mm}$ & Kuat \\
$5-10 \mathrm{~mm}$ & Sedang \\
$<5 \mathrm{~mm}$ & Lemah \\
\hline
\end{tabular}

Analisis Data

Data diameter zona hambat pada inkubasi ke-24 jam dan ke-48 jam, dianalisis dengan Analysis of Variance (ANOVA) satu jalur. Analisis data statistik dilakukan menggunakan program SPSS versi 21. Apabila diperoleh hasil yang menunjukkan beda nyata maka dilanjutkan dengan uji Duncan dengan taraf signifikasi $\alpha=0,05$ (Triyuliana, 2007). Data 
yang diperoleh disajikan dalam bentuk tabel, grafik dan gambar.

\section{HASIL DAN PEMBAHASAN}

Hasil

Pengujian aktivitas antibakteri diberikan lima perlakuan, diantaranya dua perlakuan kontrol negatif (akuades) dan positif (amoxicillin), dan tiga perlakuan fraksi metanol buah lakum (C. trifolia) dengan konsentrasi 0,3 , 0,6 dan 0,9 g/mL. Semakin tinggi konsentrasi fraksi metanol buah lakum $(C$. trifolia) yang digunakan, maka zona hambat yang terbentuk mengalami peningkatan diameter, walaupun diameter zona hambat tidak berbeda jauh.

Berdasarkan hasil penelitian, (Gambar 2) rata-rata diameter zona hambat pada jam inkubasi ke-24 hingga jam inkubasi ke-48, mengalami sedikit peningkatan rata-rata diameter zona hambat, dari perlakuan fraksi metanol buah lakum (C. trifolia) terhadap bakteri Streptococcus sp. (L.10.3), dengan kategori respon hambat sedang dan untuk kategori antimikrobabersifat bakteriosid (Tabel 2). Kontrol positif yang digunakan adalah amoxicillin untuk bakteri Streptococcus sp. (L.10.3). Hasil menggunakan antibiotic amoxicillin menunjukkan rata-rata diameter zona hambat lebih besar dari perlakuan fraksi metanol buah lakum (C. trifolia), namun mengalami penurunan rata-rata diameter zona hambat pada inkubasi jam ke-48. Respon hambat amoxicillin kategori kuat hingga sangat kuat dan untuk kategori antimikroba bersifat bakteriostatik (Tabel 2).

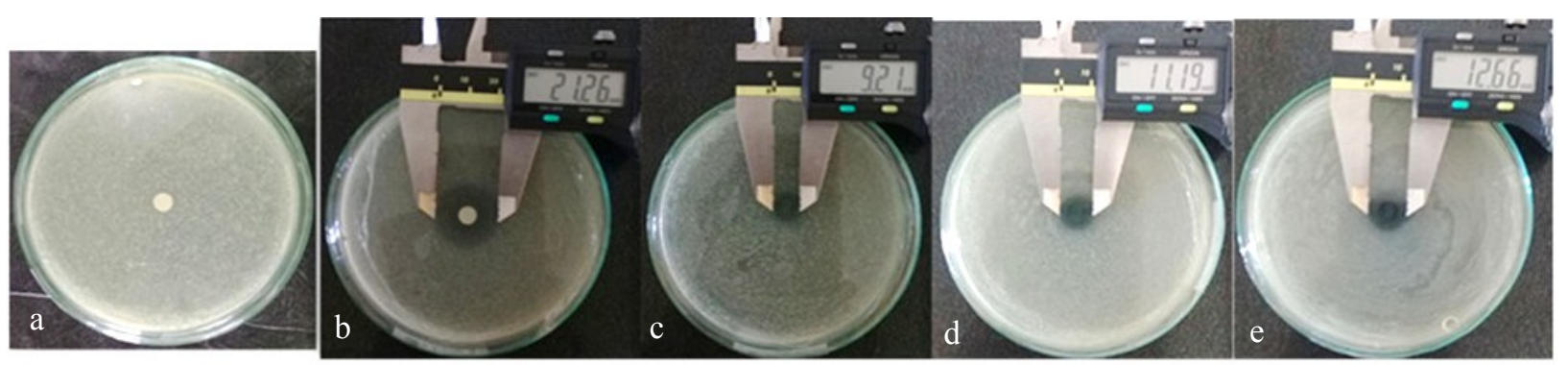

Gambar 2. Zona hambat yang terbentuk pada media Muller Hinton Agar (MHA) pada inkubasi jam ke-24 terhadap bakteri Streptococcus sp. (L.10.3), menggunakan tiga ulangan dari perlakuan (a) akuades sebagai kontrol negatif (b) amoxicillin sebagai kontrol positif, (c) Perlakuan 1 konsentrasi 0,3 g/mL fraksi metanol buah lakum ( $C$. trifolia), (d) Perlakuan 1 konsentrasi 0,6 g/mL fraksi metanol buah lakum (C. trifolia) dan (e) Perlakuan 1 konsentrasi $0,9 \mathrm{~g} / \mathrm{mL}$ fraksi metanol buah lakum (C. trifolia).

Tabel 2. Rerata Diameter Zona Hambat Bakteri Streptococcus sp. (L.10.3) Selama Inkubasi ke-24 dan 48 Jam

\begin{tabular}{|c|c|c|c|c|c|c|c|}
\hline \multirow[b]{2}{*}{ Perlakuan } & \multicolumn{3}{|c|}{24 Jam } & \multicolumn{3}{|c|}{$48 \mathrm{Jam}$} & \multirow{2}{*}{$\begin{array}{l}\text { Kategori Sifat } \\
\text { Antibakteri }\end{array}$} \\
\hline & $\begin{array}{l}\text { Rata-rata } \\
(\mathrm{mm})\end{array}$ & Std. Dev & $\begin{array}{c}\text { Respon } \\
\text { Hambatan }\end{array}$ & $\begin{array}{l}\text { Rata-rata } \\
\text { (mm) }\end{array}$ & Std. Dev & $\begin{array}{c}\text { Respon } \\
\text { Hambatan }\end{array}$ & \\
\hline $\begin{array}{l}\text { Akuades } \\
1 \mathrm{~mL}\end{array}$ & $0,00 \mathrm{~mm}$ & $0,00^{\mathrm{a}}$ & Lemah & $0,00 \mathrm{~mm}$ & $0,00^{\mathrm{a}}$ & - & - \\
\hline $\begin{array}{l}\text { Amoxicillin } 0,1 \\
\mathrm{~g} / \mathrm{mL}\end{array}$ & $29,19 \mathrm{~mm}$ & $0,17^{\mathrm{d}}$ & Sangat Kuat & $20,35 \mathrm{~mm}$ & $0,95^{\mathrm{c}}$ & Sangat Kuat & Bakteriostatik \\
\hline $\mathrm{P} 1(0,3 \mathrm{~g} / \mathrm{mL})$ & $7,70 \mathrm{~mm}$ & $1,00^{\mathrm{b}}$ & Sedang & $8,70 \mathrm{~mm}$ & $1,04^{\mathrm{b}}$ & Sedang & Bakteriosid \\
\hline $\mathrm{P} 2(0,6 \mathrm{~g} / \mathrm{mL})$ & $8,89 \mathrm{~mm}$ & $1,51^{\mathrm{bc}}$ & Sedang & $10,05 \mathrm{~mm}$ & $1,03^{\mathrm{b}}$ & Sedang & Bakteriosid \\
\hline P3 $(0,9 \mathrm{~g} / \mathrm{mL})$ & $10,72 \mathrm{~mm}$ & $1,40^{\mathrm{c}}$ & Sedang & $10,37 \mathrm{~mm}$ & $1,97^{\mathrm{b}}$ & Sedang & Bakteriosid \\
\hline
\end{tabular}

Keterangan: Angka yang ditandai huruf yang sama dalam satu kolom menunjukkan "berbeda tidak nyata". Angka yang ditandai huruf yang berbeda dalam satu kolom menunjukkan "berbeda nyata". Angka yang ditandai huruf yang berbeda antara kolom yang satu dengan kolom yang lain menunjukkan "berbeda nyata".

$\mathrm{P} 1=$ Perlakuan 1 dengan konsentrasi fraksi metanol buah lakum (C. trifolia) $0,3 \mathrm{~g} / \mathrm{mL}$ $\mathrm{P} 2=$ Perlakuan 2 dengan konsentrasi fraksi metanol buah lakum (C. trifolia) $0,6 \mathrm{~g} / \mathrm{mL}$ $\mathrm{P} 3=$ Perlakuan 3 dengan konsentrasi fraksi metanol buah lakum (C. trifolia) $0,9 \mathrm{~g} / \mathrm{mL}$ 


\section{Pembahasan}

Hasil analisis rata-rata diameter zona hambat bakteri Streptococcus sp. (L.10.3) dengan pemberian perlakuan fraksi metanol buah lakum (C. trifolia) dengan konsentrasi P1 $(0,3 \mathrm{~g} / \mathrm{mL}), \mathrm{P} 2(0,6 \mathrm{~g} / \mathrm{mL})$ dan P3 $(0,9 \mathrm{~g} / \mathrm{mL})$ selama inkubasi ke-24 dan ke-48 jam adalah sebagai berikut (Tabel 2). Berdasarkan hasil analisis yang diperoleh dari pemberian fraksi metanol buah lakum (C. trifolia) sebagai antimikroba, memberikan pengaruh yang berbeda nyata dalam penghambatan pertumbuhan bakteri anggota Streptococcus sp. (L.10.3) pengamatan pada inkubasi jam ke-24 $\left(\mathrm{F}_{4,10}=112,263, \mathrm{p}=0,000\right.$; ANOVA) dan pemberian fraksi metanol buah lakum (C. trifolia) sebagai antimikroba, memberikan pengaruh yang berbeda nyata dalam penghambatan pertumbuhan bakteri anggota Streptococcus sp. (L.10.3) pengamatan pada inkubasi jam ke-48 $\left(\mathrm{F}_{4,10}=22,575, \mathrm{p}=0,000\right.$; ANOVA) (Tabel 2).

Berdasarkan hasil menunjukkan bakteri Streptococcus sp. (L.10.3) pada perlakuan akuades sebagai kontrol negatif dan amoxicillin sebagai kontrol positif berbeda nyata dengan P1 $(0,3 \mathrm{~g} / \mathrm{mL}), \mathrm{P} 2(0,6$ $\mathrm{g} / \mathrm{mL})$ dan P3 $(0,9 \mathrm{~g} / \mathrm{mL})$. Fraksi buah lakum $(C$. trifolia) dari semua konsentrasi P1 $(0,3 \mathrm{~g} / \mathrm{mL}), \mathrm{P} 2$ $(0,6 \mathrm{~g} / \mathrm{mL})$ dan P3 $(0,9 \mathrm{~g} / \mathrm{mL})$ berbeda tidak nyata satu sama lain. P1 dengan konsentrasi $0,3 \mathrm{~g} / \mathrm{mL}$ fraksi buah lakum (C. trifolia) merupakan konsentrasi terendah dari perlakuan, dan P3 dengan konsentrasi $0,9 \mathrm{~g} / \mathrm{mL}$ merupakan konsentrasi tertinggi, dapat dikatakan sudah memberikan respon hambat dengan kategori sedang dalam menghambat bakteri Streptococcus sp. (L.10.3) (Tabel 2). Hal ini bisa dianggap perlakuan $\mathrm{P} 1(0,3 \mathrm{~g} / \mathrm{mL})$ merupakan konsentrasi yang efektif dari P2 $(0,6 \mathrm{~g} / \mathrm{mL})$ dan P3 $(0,9$ $\mathrm{g} / \mathrm{mL})$.

Hasil uji aktivitas fraksi metanol buah lakum $(C$. trifolia) terhadap bakteri Streptococcus sp. (L.10.3), rata-rata diameter zona hambat mengalami sedikit peningkatan dari inkubasi jam ke-24 hingga jam ke48, dengan kategori respon hambat sedang, dan sifat antimikroba dikategorikan bakteriosid, dibandingkan dengan perlakuan kontrol positif menggunakan amoxicillin dengan rata-rata diameter zona hambat kategori respon hambat sangat kuat, dan untuk kategori antibakteri bersifat bakteriostatik. Menurut Salni \& Ratna (2011), bakteri gram positif memiliki struktur dinding sel dengan lebih banyak peptidoglikan, sedikit lipid, dan dinding sel mengandung polisakarida (asam teikoat). Amoxicillin berperan aktif melawan bakteri gram positif yang tidak menghasilkan $\beta$-laktamase dan aktif melawan bakteri gram negatif karena antibiotik tersebut dapat menembus pori-pori dalam membran fosfolipid luar.

Perbedaan kategori sifat antimikroba antara fraksi metanol buah lakum dengan antibiotik amoxicillin diduga karena kandungan senyawa yang terdiri atas triterpenoid, flavonoid, dan fenolik pada buah lakum menurut Ridho (2013). Ekstrak metanol buah lakum mengandung senyawa antara lain triterpenoid, flavonoid, dan fenolik. Hasil menunjukkan bahwa senyawa tersebut dapat ditarik dengan pelarut metanol, sedangkan menurut Talogo (2014) amoxicillin tidak dapat larut dalam metanol. Amoxicillin dapat menghambat pertumbuhan bakteri dengan cara menembus pori-pori dalam membran fosfolipid luar. Sedangkan senyawa flavonoid dan fenolik dapat digunakan untuk membunuh bakteri karena menurut Maliana et al. (2013) golongan senyawa flavonoid dapat menyebabkan denaturasi protein, sehingga mengakibatkan aktivitas metabolisme sel bakteri berhenti. Senyawa flavanoid ini dapat bersifat antibakteri, karena adanya gugus fenol yang bersifat sebagai koagulator protein yang dapat mengganggu sintesis membran sel serta proses metabolisme yang menggunakan protein tidak akan terjadi (Dwidjoseputro, 2010). Menurut Harborne (2006) terpenoid dapat menyebabkan lisis pada sel bakteri dengan mengikat protein, lipid, dan atau karbohidrat yang terdapat pada membran sel. Oleh karena itu, hal ini diduga menyebabkan fraksi metanol buah lakum bersifat bakteriosid sedangkan amoxicillin bakteriostatik.

\section{DAFTAR PUSTAKA}

Angelina, M, Turnip, M \& Khotimah, S, 2015, Uji Aktivitas Antibakteri Ekstrak Etanol Daun Kemangi (Ocimum sanctum L.) terhadap Pertumbuhan Bakteri Escherichia coli dan Staphylococcus aureus, Jurnal Protobiont, vol. 4, no. 1, hal. 184-189

Davis \& Stout, 1971, Disc Plate Method of Microbiological Antibiotic Essay, Journal of Microbiology, vol. 22 , no. 4, hal. 659-665

Dwidjoseputro, 2010, Dasar-Dasar Mikrobiologi, Djambatan, Jakarta

Grubben, GJH, 2004, Plant Resources of Tropical Africa 2 Vegetables, PROTA Foundation, Belanda

Harborne, BJ, 2006, Metode Fitokimia Penuntun Cara Modern Menganalisis Tumbuhan (alih bahasa: 
Kosasih Padmawinata \& Iwang Soediro), Penerbit ITB, Bandung

Janovska, D, Katerina, K \& Ladislav, K, 2003, Screening for Antimicrobial Activity of Some Medicinal Plants Species of Traditional Chinese Medicine, Czech Journal Food Science, vol. 21, no. 3, hal. 107-110

Mahendra, B, 2010, Panduan Meracik Herbal, 1, Penebar Swadaya, Jakarta

Maliana, Y, Khotimah, S \& Diba, F, 2013, Aktivitas Antibakteri Kulit Garcinia mangostana Linn. Terhadap Pertumbuhan Flavobacterium dan Enterobacter dari Coptotermes curvignathus Holmgren, Jurnal Protobiont, vol. 2, no. 1, hal. 7-11

Nuria, MC, 2010, Antibacterial Activities From Jangkang (Homalocladium platycladum) (F. Muell) Bailey) Leaves, Jurnal Ilmu-Ilmu Pertanian, vol. 6, no. 2, hal. 9-15

Prasetyo, B, Linda, R \& Mukarlina, 2016, Pemanfaatan Tumbuhan Lakum (Cayratia trifolia (L.) Domin.) Oleh Etnis Melayu Di Kecamatan Sungai Kunyit Kabupaten Mempawah, Jurnal Protobiont, vol. 5, no. 2, hal. 25-33

Putri, AVAA, Hafida, N \& Megawati, V, 2017, Pengaruh Daya Antibakteri Ekstrak Daun Stevia (Stevia rebaudiana Bertoni) pada Konsentrasi 5\%, 10\%, 20\%, 40\% dan 80\% terhadap Streptococcus mutans (In Vitro), Jurnal Ilmu Kedokteran Gigi, vol. 1 , no. 1 , hal. 9-14
Ramadanti, IA, 2008, Uji Aktivitas Antibakteri Ekstrak Bawang Putih (Allium sativum Linn) terhadap Bakteri Escherichia coli In Vitro, Artikel Karya Tulis Ilmiah, Fakultas Kedokteran, Universitas Diponegoro, Semarang

Ridho, EA, 2013, Uji Aktivitas Antioksidan Ekstrak Metanol Buah Lakum (Cayratia trifolia) Dengan Metode DPPH (2,2-DIFENIL-1-PIKRILHIDRAZIL), Skripsi, Universitas Tanjungpura, Pontianak

Salni, HM \& Ratna, WM, 2011, Isolasi Senyawa Antibakteri Dari Daun Jengkol (Pithecolobium lobatum Benth) dan Penentuan Nilai KHM-nya, Jurnal Penelitian Sains, vol. 14, no. 1, hal. 3841

Susanti, L, Wardoyo, ERP \& Kurniatuhadi, R, 2018, Aktivitas Biologis Asap Cair Batang Manggis (Garcinia mangostana L.) terhadap Viabilitas Streptococcus sp. (L.10.3), Jurnal Protobiont, vol. 7, no. 3, hal. 1-8

Talogo, ASM, 2014, Pengaruh Waktu dan Temperatur Penyimpanan Terhadap Tingkat Degradasi Kadar Amoksisilin Dalam Sediaan Suspensi AmoksisilinAsam Klavulanat, Skripsi, Program Studi Farmasi, Fakultas Kedokteran dan Ilmu Kesehatan, Universitas Syarif Hidayatullah Jakarta

Triyuliana, AH, 2007, Panduan Praktis, Pengolahan Data Statistik dengan SPSS 15.0, Semarang

Wulandari, C, Rousdy, DW \& Wardoyo, ERP, 2018, Skrining Fitokimia Berbagai Fraksi Ekstrak Buah Lakum (Cayratia trifolia L.), Jurnal Protobiont, vol. 7 , no. 2 , hal. $66-70$ 